\title{
ASSESSMENT OF THE ALLELOPATHIC POTENTIAL AND IDENTIFICATION OF THE PHYTOTOXIC SUBSTANCES FROM THE STRAW OF BANGLADESHI INDIGENOUS RICE VARIETY 'GORIA'
}

\author{
Masum, S. M. ${ }^{1,2}$ - AKAmine, H. ${ }^{3}-$ Hossain, M. A. ${ }^{3 *}$-SAKAGAMI, J. I. ${ }^{4}-$ IshiI, T. ${ }^{3}$ - Gima, S. ${ }^{5}$ \\ ${ }^{I}$ United Graduate School of Agriculture Sciences, Kagoshima University, Kagoshima, Japan \\ ${ }^{2}$ Department of Agronomy, Sher-e-Bangla Agricultural University, Dhaka, Bangladesh \\ ${ }^{3}$ Faculty of Agriculture, University of the Ryukyus, Okinawa, Japan \\ ${ }^{4}$ Faculty of Agriculture, Kagoshima University, Kagoshima, Japan \\ ${ }^{5}$ CRAC, University of the Ryukyus, Okinawa, Japan \\ *Corresponding author \\ e-mail:amzad@agr.u-ryukyu.ac.jp; phone: +81-98-895-8824
}

The first two authors contributed equally to this work.

(Received 28 ${ }^{\text {th }}$ Mar 2020; accepted $2^{\text {nd }}$ Jul 2020)

\begin{abstract}
Straw from Bangladeshi indigenous rice (Oryza sativa L. ssp. indica) variety 'Goria' was incorporated into a gray soil to observe the phytotoxic effects on Echinochloa oryzicola. The residues of 'Goria' caused inhibition on the growth and dry weight of E. oryzicola. The rate of 'Goria' straw incorporation was sequentially evaluated to observe autotoxicity in the cultivation of the same rice variety. An improvement was found on the growth and yield parameters of rice due to the straw incorporation into the soil. Aqueous methanol extracts of 'Goria' straw inhibited the seedling growth of Lepidium sativum $\mathrm{L}$. and E. oryzicola, which suggested that this variety might contain phytotoxic

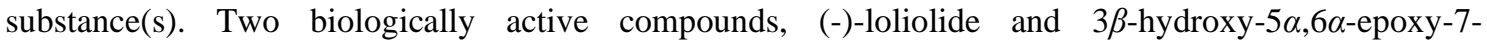
megastigmen-9-one, were isolated using several chromatographic steps. The phytotoxic potential of these two compounds was assayed in vitro on the seedling growth of test flora to validate it. The inhibitory activity of $3 \beta$-hydroxy-5 $\alpha, 6 \alpha$-epoxy-7-megastigmen-9-one was greater than that of (-)-loliolide, as demonstrated by comparison of the $I_{50}$ values. However, the two compounds synergistically suppressed the growth of $L$. sativum and E. oryzicola more strongly than the individual compounds. The results suggest that incorporation of allelopathic rice Goria-straw could help suppress E. oryzicola in rice to achieve non-herbicidal weed control.
\end{abstract}

Keywords: allelochemicals, autotoxicity, inhibitory bioactivity, Echinochloa oryzicola, weed management

\section{Introduction}

Rice (Oryza sativa L. ssp. indica) is the primary crop of Bangladesh, covering approximately $75 \%$ of the total crop area (BBS, 2017). The dramatic increase in the use of agricultural chemicals has contributed considerably to increasing rice productivity worldwide and in Bangladesh in the last half century (Erisman et al., 2008). However, in Bangladesh, rice cultivation is seriously threatened by several factors and circumstances including pesticide and fertilizer use. The current trend in agriculture focuses on reducing the use of herbicides because of their adverse effects on nature. Anxiety about the potential connections between public health, environmental 
conditions, and farming output exposes the rising demand to address the long-term sustainability of existing agricultural practices and determine which agricultural technologies will be safe and economically productive.

Rice is heavily infested with several noxious weeds, including E. crus-galli (Kraehmer et al., 2016). In Bangladesh, E. oryzicola is one of the primary weeds, which is difficult to control because it is a mimic of rice and easily adapts to both the transplanted and direct-sowing rice growing environments. Several methods are used to control weeds. Depending on the weed types and critical period of weed competition, we must intelligently select and adopt different weed management techniques based on the available resources. Allelopathy is a phytotoxic inference in which a plant or plant residue releases phytochemicals exerting an impact (generally adverse) on the adjacent or successive plants (Yang and Kong, 2017; Kong et al., 2019). Using allelopathy in crop production, reducing synthetics and ensuing environmental degradation, and developing efficient methods for sustainable crop production and agroecological schemes are the primary motivations for research on allelopathy (Han et al., 2013).

To develop herbicides, allelochemicals have been on the research interest of phytochemists recently (Chung et al., 2017). A tremendous opportunity is available to use rice residues as a source of bio-herbicides (Amb and Ahluwalia, 2016). Mulching or incorporation of allelopathic plant materials provides convenient weed management (Jabran et al., 2015) and reduces the adverse effects on an agroecosystem (Cheema et al., 2004). The adoption of mechanized agriculture has brought in leaving a significant amount of rice straw that is available for most rice farmers as organic material. Thus, we can use this rice straw for recycling in agricultural practices. Chung et al. (2001) and Xuan et al. (2005) describe suppression activities of rice residues on weeds including Echinochloa species. The content of phytotoxic compounds in rice straw is vast and manifold (Kong et al., 2006; Kato-Noguchi et al., 2012). Significant amounts of stubble remained in the fields after rice harvest also contain and release phytotoxins (Kong et al., 2006; Cao et al., 2008) and reduce soil erosion and effectively prohibit the growth of weeds (Ramakrishna et al., 2006). Furthermore, removal of straw from the field diminishes reserves of soil $\mathrm{K}$ and $\mathrm{Si}$, whereas incorporation of the remaining plant parts into the soil deposits nutrients and assists in conserving soil nutrient resources for an extended period (Dobermann and Fairhurst, 2002). Thus, straw incorporation can increase soil fertility and improve soil organic matter content, which can influence the nutritional and physiological aspects of crop growth. Generally, rice straw is applied back into rice and vegetable fields as an organic substance, and particularly in greenhouse cropping. Rice straw mulching had a notable impact on controlling weed growth under zero tillage wheat (Triticum aestivum L.) in experimental field conditions following rice in Bangladesh (Rahman et al., 2005). Hence, weed prevention coupled with yield enhancements by rice straw mulching would benefit integrated weed management systems, while minimizing the effects of agrochemicals, which are an essential concern in current agricultural activities. Regrettably, Schreiber (1992), Lund et al. (1993) and Inderjit et al. (2004) conveyed that the incorporation of straw into the soil was the primary cause for the suppression of crop growth in the next season.

Evolution of weed resistance against herbicides demands that new classes of herbicides are created with new modes of action that have not been previously exploited and that can be used in organic agriculture. Moreover, using synthetics for weed suppression also requires public acceptance (Dayan et al., 2009; Anwar et al., 2019). Allelochemicals can be familiarized as potential natural herbicides because of their 
inhibitory activities on the emergence, growth, physiological response, and biochemical contents of receivers (Weir et al., 2004; Khanh et al., 2009), which ultimately manipulate the population structure and dynamics during secondary succession of flora, their vegetation pattern in communities, and farm management and output (Weidenhamer and Callaway, 2010). In agriculture, allelochemicals are considered as a supplement because they are less persistent and eco-friendly (Weston and Duke, 2003). Allelopathic substances such as momilactones $\mathrm{A}$ and $\mathrm{B}$, form rice straw and their phytotoxic inference on weeds have been documented (Chung et al., 2001). Therefore, the present study was planned to consider the use of Bangladeshi indigenous rice straw for the control of weeds, to observe autotoxicity in rice, and to isolate and identify potential phytotoxic substances and determine their bioactivity on the growth of $E$. oryzicola.

\section{Materials and methods}

\section{Plant materials}

The Bangladesh indigenous rice (Oryza sativa L. spp. indica) variety 'Goria' as allelopathic (Masum et al., 2016) were grown in pots (Wagner pot, $0.02 \mathrm{~m}^{2}$ ) from April to July 2016 in a glasshouse of the University of the Ryukyus for 120 days and then allowed to sundry in the glasshouse for an additional period (21 days). Seeds of $L$. sativum L. were purchased from the Green Field Project (Kumamoto, Japan), and seeds of Echinochloa crus-galli L. Beauv. var. oryzicola were collected from the rice field of the University of the Ryukyus, Japan.

\section{Pot studies}

Pot (Wagner pot, area $0.02 \mathrm{~m}^{2}$; height $19.7 \mathrm{~cm}$; diameter $17.3 \mathrm{~cm}$ ) studies were undertaken in a two-step procedure, with both steps conducted in a glasshouse at the University of the Ryukyus, Japan. The first step was to verify the effect of rice straw incorporation into the soil on E. oryzicola growth, and the second step was to observe rice growth. In the first step, each pot was filled with $4 \mathrm{~kg}$ of gray soil (coarse sand $3.61 \%$, fine sand $30.94 \%$, silt $24.32 \%$, and clay $32.84 \%$; apparent density $0.90 \mathrm{~g} \mathrm{~cm}^{-3}$; $\mathrm{pH} 7.43$; $\mathrm{C} 1.83 \%$ and $\mathrm{N} 0.14 \%$; and in $\mathrm{mg} \mathrm{g}^{-1}$ soil, $\mathrm{HPO}_{4}{ }^{2-} 0.44, \mathrm{~K}^{+} 0.75, \mathrm{Ca}^{2+} 4.99$, $\mathrm{Mg}^{2+} 0.70, \mathrm{SO}_{4}^{2-} 1.39, \mathrm{Fe}^{3+} 0.64, \mathrm{Mn}^{2+} 0.41, \mathrm{Zn}^{2+} 0.47, \mathrm{Na}^{2+} 1.01, \mathrm{Cu}^{2+} 0.41$, and $\mathrm{Al}^{2+}$ $0.81)$. Soils with the chaff $(1-2 \mathrm{~cm})$ of 'Goria' rice at the rate of $0.5,1.0,1.5$ and $2.0 \mathrm{t} \mathrm{ha}^{-1}$ were completely incorporated in pots. The untreated pots contained soil only. The incorporated soils were moistened for 30 days to decompose appropriately. Two pre-germinated E. oryzicola seeds were placed in each pot. Weed-inhibition was determined from the difference of the growth parameters and dry weights of plants between treated and untreated pots.

In the second step, each pot was filled as in the first step, and four treatments were applied: control, 'Goria' straw (2.0 t ha $\left.{ }^{-1}\right)$, commercial fertilizers, and 'Goria' straw $\left(2.0 \mathrm{t} \mathrm{ha}^{-1}\right)$ with commercial fertilizers. Residues were decomposed as previously described. Commercial fertilizers were applied at the rate of $0.063,0.05,0.025,0.031$, and $0.005 \mathrm{~g} \mathrm{~kg}^{-1}$ soil in the form of urea, triple superphosphate (TSP), muriate of potash (MOP), gypsum and zinc sulphate, respectively, one day before transplanting; urea was applied in three equal splits one day before transplanting and at 20 and 40 DAT (days after transplanting). Twenty-five-day-old seedlings of Bangladesh 
indigenous rice variety 'Goria' were transplanted at 1 seedling per pot. Growth and yield contributing parameters of rice were observed. After the harvest of the crop, the experimental soil core was carefully removed from the pot. About $200 \mathrm{~g}$ of soil samples were collected from the inner area of the core up to bottom layer at $5-\mathrm{cm}$ intervals, air-dried, grounded, and the roots were separated by sieving with a 2.5 -mesh sieve.

\section{Straw extract bioassay}

Dried straw (leaves and stems) of 'Goria' variety was blended and kept at $-40{ }^{\circ} \mathrm{C}$ until used for extraction. Extraction was performed using a slight modification of the method developed by Kato-Noguchi et al. (2011). The powder (40 g) placed in a 1000$\mathrm{mL}$ flask containing $500 \mathrm{~mL}$ of $80 \%$ (v/v) aqueous methanol, and stirred for $48 \mathrm{~h}$ at room temperature. Extracts were filtered through Whatman No. 42 filter paper (Toyo, Tokyo, Japan). The residue was re-extracted with $500 \mathrm{~mL}$ of methanol and filtered following the above methods. Then, the two filtrates were mixed and evaporated to dryness in vacuo.

An aliquot of the aqueous concentrate $(0.001,0.003,0.01,0.03,0.1$ and $0.3 \mathrm{~g}$ dry weight [DW] equivalent extract per $\mathrm{mL}$ final assay concentration) was evaporated to dryness on a rotary evaporator at $40{ }^{\circ} \mathrm{C}$. Then, the dried sample was re-dissolved in cold methanol $(0.2 \mathrm{~mL})$, placed on a sheet of filter paper (no. 2) in a $3 \mathrm{~cm}$ Petri dish, desiccated in a draft chamber and then soaked in $0.8 \mathrm{~mL}$ of $0.05 \%(\mathrm{v} / \mathrm{v})$ aqueous solution of Tween 20 (polyoxyethylene sorbitan monolaurate; Nacalai Tesque Inc., Kyoto, Japan) as a surfactant. For the control treatments, methanol $(0.2 \mathrm{~mL})$ was used and desiccated as described above. Ten uniform germinated seedlings of $L$. sativum or E. oryzicola were placed on the filter paper and then incubated at $25{ }^{\circ} \mathrm{C}$ in a dark incubator. The root and shoot lengths of the test species were determined after $48 \mathrm{~h}$ of incubation. The percentage of growth inhibition was calculated with respect to the control (without extracts) seedlings.

\section{Extraction of rice straw for purification of growth inhibitors}

Extracts were prepared using the method described by Kato-Noguchi et al. (2011) for isolating allelochemicals. A total of $2.4 \mathrm{~kg}$ of finely ground dry straw was extracted as described above. Then, the supernatant was concentrated under vacuum to prepare the aqueous concentrate $(100 \mathrm{~mL})$. This aqueous concentrate was adjusted to $\mathrm{pH} 7.0$ and suspended in ethyl acetate and evaporated to obtain ethyl acetate extracts $(12.4 \mathrm{~g})$. The active ethyl acetate fraction was chromatographed on a column of silica gel ( $70 \mathrm{~g}$, silica gel 60N, 70-230 mesh; ASTM, Kanto Chemical Co., Inc., Tokyo, Japan), eluting with a stepwise gradient of ethyl acetate (each step 10\%, v/v; $150 \mathrm{~mL}$ ) and methanol $(300 \mathrm{~mL})$ in n-hexane, affording 11 fractions. The inhibition effect of the collected fractions was scrutinized using the L. sativum growth bioassay according to the above procedure, and complete inhibition was observed in fractions attained by elution with $80 \%$ ethyl acetate in n-hexane. After drying, the concentrate $(1.4 \mathrm{~g})$ was filtered through a column of Sephadex LH-20 (60 g, GE Healthcare Bio-Sciences AB SE-75184; Uppsala, Sweden), eluting with aqueous methanol $(20,40,60$ and $80 \%, \mathrm{v} / \mathrm{v} ; 150 \mathrm{~mL}$ each step) and methanol (300 mL). The most effective fraction was eluted with $60 \%$ aqueous methanol and subsequently concentrated until dryness. The concentrate $(254 \mathrm{mg})$ was dissolved in $20 \%$ aqueous methanol (v/v, $2 \mathrm{~mL})$ and loaded onto a reverse-phase C18 Sep-Pak 
cartridge (Waters Corporation, Milford, Massachusetts, USA) and purified with aqueous methanol $(20,40,60$, and $80 \%, \mathrm{v} / \mathrm{v})$ and methanol (15 mL each step). The most effective fraction (20\% aqueous methanol) concentrated until dryness. The concentrate (71 mg) was finally purified by C18 reversed-phase HPLC (COSMOSIL 5C18-AR-II; Nacalai Tesque, Inc., Kyoto, Japan), eluting with 50\% aqueous methanol at a flow rate of $3 \mathrm{~mL} / \mathrm{min}$ and detecting at $220 \mathrm{~nm}$. Complete inhibition was detected for two peaks that eluted at 22.0 and $24.0 \mathrm{~min}$ as colorless substances. Mass spectrometry with electro-spray ionization (ESI-MS) analysis was conducted on a Waters mass spectrometer. NMR spectra were computed on a Bruker NMR spectrometer $(500 \mathrm{MHz}$ for $1 \mathrm{H}$ and $125 \mathrm{MHz}$ for $13 \mathrm{C}$ ), available at the Central Instrumental Center, University of the Ryukyus. All chemical shifts were reported relative to tetramethylsilane (TMS). Optical rotation was calculated in chloroform on a JASCO P-1010 polarimeter. There are two kinds of compounds were isolated and identified in this study. Soil nutrient contents were also measured where $\mathrm{N}$ and C by NC-220F (SUMIGRAPH Model, Sumika Analysis Services Ltd., Osaka, Japan) and rest nutrients by ICPE-9000 (ICPAES Multitype ICP Emission Spectrometer, SHIMADZU, Kyoto, Japan).

\section{Evaluation of biological activities of the compounds}

The isolated compounds were dissolved in methanol to make the concentrations of $0.01,0.03,0.1,0.3,1,3,10,30,100,300$ and $1000 \mu \mathrm{M}$ for each compound, in addition to $0.01,0.03,0.1,0.3,1,3,10,30,100$ and $300 \mu \mathrm{M}$ for a mixture of the two compounds at the ratio of $8: 3$, with the concentration the sum of the both phytochemicals. The biological activity against $L$. sativum and E. oryzicola seedlings was examined using the above procedure.

\section{Statistical analysis}

Linear regression was used to determine the relationship between the rates of materials (straw, extracts, and compounds) and their effects on the test plants, and Fisher's Protected Least Significant Difference test was used for mean separations. The experimental designs were completely randomized with triplicates. The Type I error was set at 0.05 and 0.01 for all statistical comparisons. The $I_{50}$ (concentration of approximately $50 \%$ inhibition of the growth rate) value in the assays was calculated from the regression equation of the concentration curves.

\section{Results}

\section{Pot studies}

Residues of tested rice inhibited the growth parameters and dry matter of $E$. oryzicola at the highest amounts of 1.5 and $2 \mathrm{t} \mathrm{ha}^{-1}$, whereas less straw incorporation had no effect (Fig. 1). In the second step of the pot studies, the growth and yield contributing parameters of 'Goria' rice were not significantly different between commercial fertilizer application and the combination of straw incorporation with commercial fertilizer (Table 1). However, positive responses were observed in the parameters for the combination of straw incorporation and commercial fertilizers, except for panicle length (Fig. 2). Based on the results of soil analysis after harvest, numerically highest amount of plant nutrients remained under the combination of straw incorporation and commercial fertilizers (Table 2). 


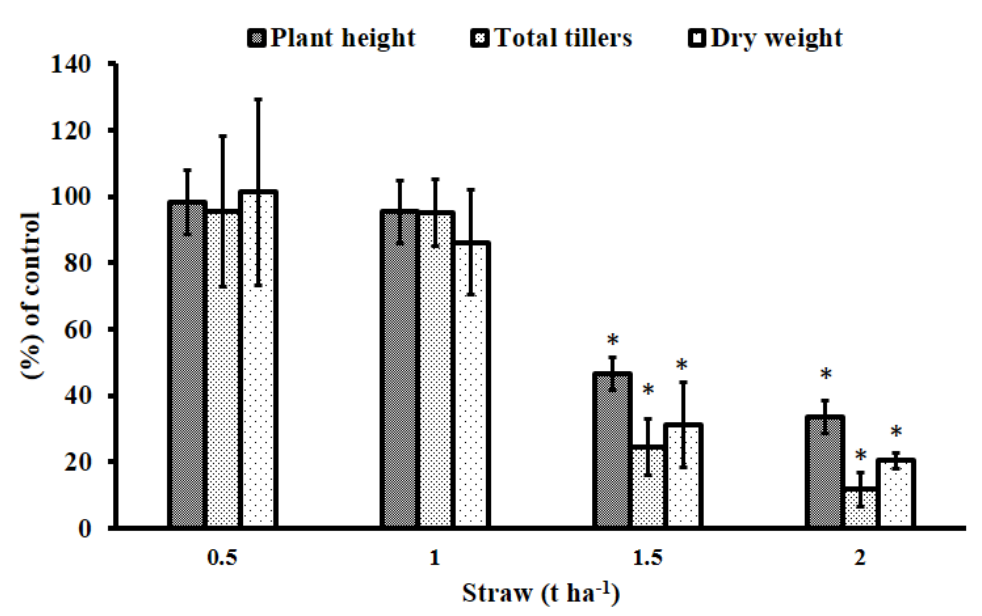

Figure 1. Effect of straw incorporation on growth and dry weight of E. oryzicola. Bars represent $\pm S D$ of values obtained from three biological replicates. Asterisks indicate significant differences between the control and treatment: $* P<0.01$

Table 1. Effect of allelopathic straw incorporation into the soil on growth and yield contributing parameters of Bangladesh indigenous rice variety 'Goria'

\begin{tabular}{|c|c|c|c|c|c|c|c|}
\hline Treatment & $\begin{array}{c}\text { Plant height } \\
\text { (cm) }\end{array}$ & \begin{tabular}{|c|} 
Total tillers \\
plant $^{-1}$ \\
(Nos.) $^{-}$
\end{tabular} & \begin{tabular}{|c|}
$\begin{array}{c}\text { Effective } \\
\text { tillers plant }^{-1} \\
\text { (Nos.) }\end{array}$ \\
\end{tabular} & $\begin{array}{c}\text { Panicle } \\
\text { length }(\mathrm{cm})\end{array}$ & $\begin{array}{c}\text { Total grain } \\
\text { plant }^{-1} \\
\text { (Nos.) }^{-}\end{array}$ & $\begin{array}{c}\text { Filled grain } \\
\text { percentage }^{\text {plant }} \mathbf{t}^{-1} \\
\end{array}$ & $\begin{array}{c}\text { Thousand } \\
\text { seed weight } \\
\text { (g) }\end{array}$ \\
\hline Control & $87.67 \pm 2.52^{\mathrm{c}}$ & $5.33 \pm 0.58^{\mathrm{c}}$ & $2.67 \pm 0.58^{\mathrm{c}}$ & $18.33 \pm 1.53^{\mathrm{b}}$ & $49.26 \pm 7.76^{c}$ & $46.91 \pm 9.74^{\mathrm{c}}$ & $17.98 \pm 0.21^{\mathrm{b}}$ \\
\hline Straw $2 \mathrm{t} \mathrm{ha}^{-1}$ & $109.00 \pm 3.61^{\mathrm{b}}$ & $17.00 \pm 1.00^{\mathrm{b}}$ & $4.00 \pm 1.00^{\mathrm{b}}$ & $19.00 \pm 1.00^{\mathrm{b}}$ & $72.83 \pm 2.72^{\mathrm{b}}$ & $74.30 \pm 5.88^{\mathrm{b}}$ & $18.26 \pm 0.18^{b}$ \\
\hline Chemical Fertilizer & $117.67 \pm 2.52^{\mathrm{a}}$ & $25.67 \pm 1.53^{\mathrm{a}}$ & $8.33 \pm 1.53^{\mathrm{a}}$ & $20.73 \pm 0.64^{\mathrm{a}}$ & $89.60 \pm 2.11^{\mathrm{a}}$ & $96.03 \pm 2.36^{\mathrm{a}}$ & $20.09 \pm 0.70^{\mathrm{a}}$ \\
\hline Chemical fertilizer + Straw $2 \mathrm{tha}^{-1}$ & $120.67 \pm 3.06^{\mathrm{a}}$ & $26.33 \pm 2.08^{\mathrm{a}}$ & $9.33 \pm 0.58^{\mathrm{a}}$ & $20.50 \pm 0.50^{\mathrm{a}}$ & $90.55 \pm 2.36^{\mathrm{a}}$ & $96.96 \pm 2.14^{\mathrm{a}}$ & $20.21 \pm 0.79^{\mathrm{a}}$ \\
\hline
\end{tabular}

Means having similar letter(s) in a column are statistically similar and those having dissimilar letter(s) differ significantly at 0.01 level of probability

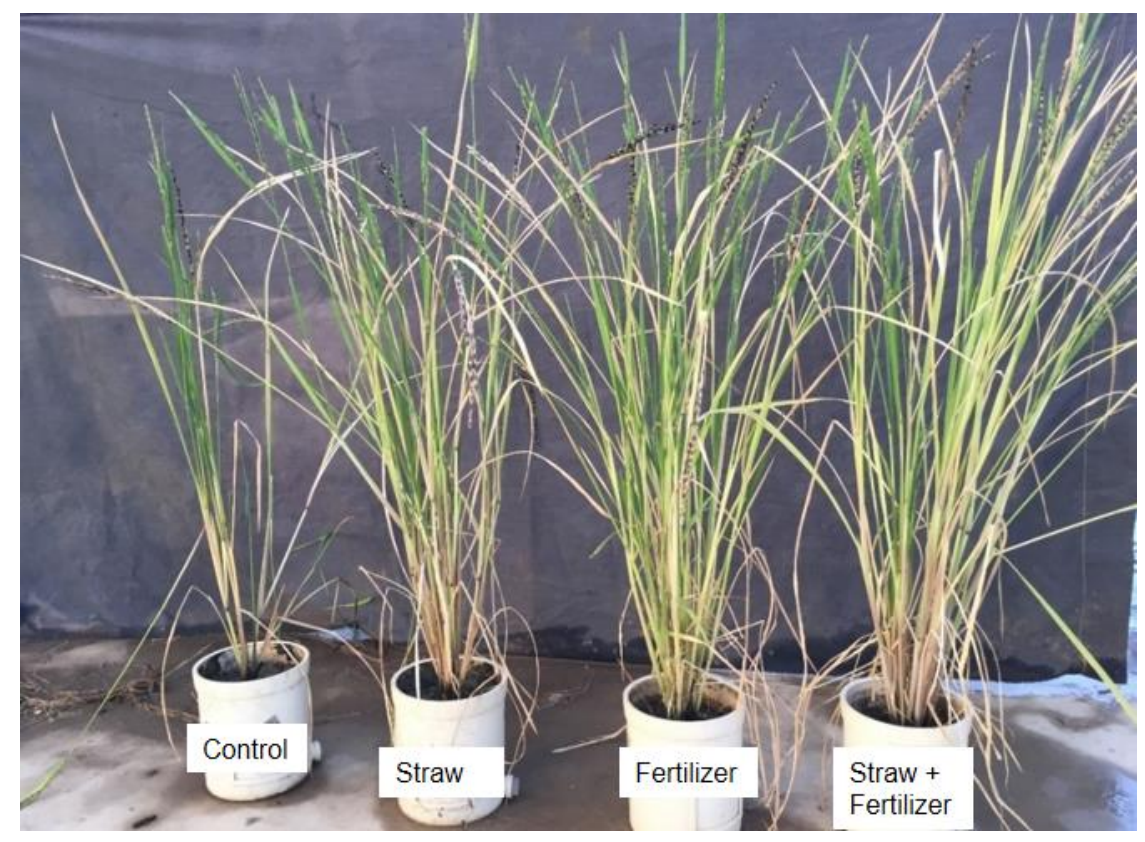

Figure 2. Effect of Bangladesh indigenous rice variety 'Goria' straw incorporation on same rice variety 
Table 2. Effect of straw incorporation into the soil on plant nutrients in soil after rice harvest

\begin{tabular}{|c|c|c|c|c|c|c|c|c|c|}
\hline \multirow[b]{2}{*}{ Treatment } & \multicolumn{9}{|c|}{ Plant nutrients } \\
\hline & $\mathrm{C}(\%)$ & $\mathbf{N}$ & $\mathrm{HPO}_{4}{ }^{2-}$ & $\mathbf{K}^{+}$ & $\begin{array}{c}\mathrm{Ca}^{2+} \\
\left(\mathrm{mg} \mathrm{g}^{-1} \text { soil }\right)\end{array}$ & $\mathrm{SO}_{4}{ }^{2-}$ & $\mathbf{M g}^{2+}$ & $\mathrm{Fe}^{3+}$ & $\mathbf{Z n}^{2+}$ \\
\hline Control & $1.61 \pm 0.02$ & $0.11 \pm 0.01$ & $0.34 \pm 0.01$ & $0.63 \pm 0.08$ & $4.60 \pm 0.33$ & $1.25 \pm 0.01$ & $0.65 \pm 0.06$ & $0.47 \pm 0.01$ & $0.46 \pm 0.01$ \\
\hline Straw $2 \mathrm{t} \mathrm{ha}^{-1}$ & $1.77 \pm 0.12$ & $0.13 \pm 0.01$ & $0.42 \pm 0.13$ & $0.74 \pm 0.08$ & $5.01 \pm 0.34$ & $1.38 \pm 0.15$ & $0.70 \pm 0.06$ & $0.64 \pm 0.30$ & $0.47 \pm 0.03$ \\
\hline $\begin{array}{l}\text { Chemical } \\
\text { fertilizer }\end{array}$ & $1.87 \pm 0.06$ & $0.14 \pm 0.01$ & $0.36 \pm 0.02$ & $0.67 \pm 0.09$ & $4.72 \pm 0.19$ & $1.40 \pm 0.04$ & $0.63 \pm 0.07$ & $0.47 \pm 0.01$ & $0.45 \pm 0.01$ \\
\hline $\begin{array}{c}\text { Chemical } \\
\text { fertilizer } \\
+ \text { straw } 2 \mathrm{t} \mathrm{ha}^{-1} \\
\end{array}$ & $2.23 \pm 0.01$ & $0.16 \pm 0.01$ & $0.36 \pm 0.02$ & $0.73 \pm 0.05$ & $4.53 \pm 0.30$ & $1.47 \pm 0.33$ & $0.70 \pm 0.06$ & $0.48 \pm 0.01$ & $0.45 \pm 0.01$ \\
\hline
\end{tabular}

\section{Phytotoxic effects of aqueous methanol extracts}

High concentrations of the aqueous methanol extracts inhibited the growth of the test species; whereas with very low concentrations ( $0.01 \mathrm{~g}$ DW equivalent per $\mathrm{mL}$ ), stimulation or no effect on test species was observed (Fig. 3A, B). At $0.3 \mathrm{~g}$ DW equivalent extract per $\mathrm{mL}$ of rice plants, the root growth of L. sativum and E. oryzicola was 3 and 5\% compared with that of the control root, respectively. At the same concentration, the shoot growth of L. sativum and E. oryzicola was 6 and $29 \%$ of control shoot growth, respectively. The obtained results reveal that the rice straw of 'Goria' may have potential growth inhibitory allelopathic substances.
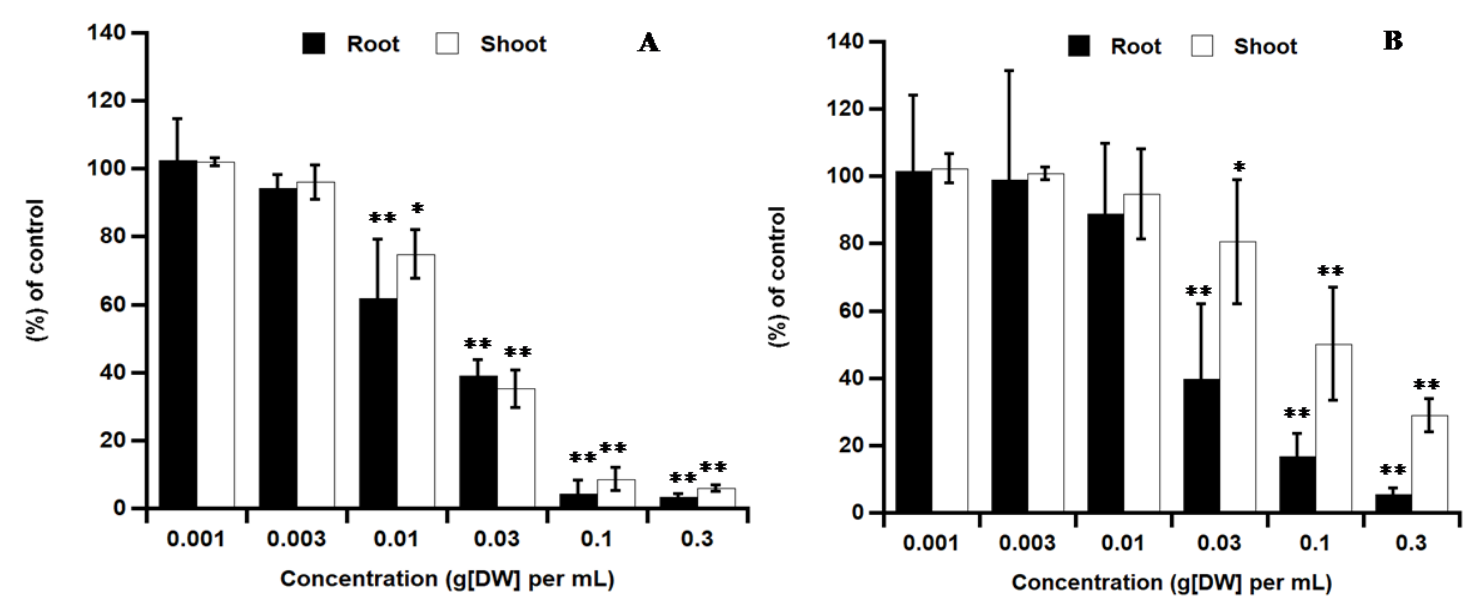

Figure 3. Effect of aqueous methanol-extract of rice straw on root and shoot growth of $L$. sativum (A) and E. oryzicola $(B)$. Bars represent $\pm S D$ of values obtained from three biological replicates. Asterisks indicate significant differences between the control and treatment:

$$
* P<0.05 ; * * P<0.01
$$

\section{Structural identification of isolated compounds}

Two biologically active compounds were obtained from the repeated column chromatography of the aqueous methanol extracts of Bangladeshi rice straw variety 'Goria'.

Compound 1 (3.8 mg) had a molecular formula of $\mathrm{C}_{11} \mathrm{H}_{16} \mathrm{O}_{3}$ (LR-ESI-MS $\mathrm{m} / z 197$ $\left.[\mathrm{M}+\mathrm{H}]^{+}\right)$and a specific rotation of $[\alpha]_{\mathrm{D}}{ }^{20}-68.8(c 0.01, \mathrm{MeOH})$. The following were 
obtained for NMR spectra: ${ }^{1} \mathrm{H}-\mathrm{NMR}\left(500 \mathrm{MHz}, \mathrm{CD}_{3} \mathrm{OD}\right) \delta$ : 1.27 (3H, s, H-9), 1.47 $(3 \mathrm{H}, \mathrm{s}, \mathrm{H}-8), 1.53$ (dd, $J=14.6$ and $3.7 \mathrm{~Hz}, \mathrm{H}-7), 1.78$ (3H, s, H-10), 1.79 (dd, $J=13.5$ and $4.1 \mathrm{~Hz}, \mathrm{H}-5), 1.98$ (dt, $J=14.5$ and $2.6 \mathrm{~Hz}, \mathrm{H}-7), 2.46(\mathrm{dt}, J=14.1$ and $2.6 \mathrm{~Hz}, \mathrm{H}-$ 5), 4.33 (m, H-6), 5.70 (s, H-3); and ${ }^{13} \mathrm{C}-\mathrm{NMR}$ (125 MHz, $\left.\mathrm{CD}_{3} \mathrm{OD}\right) \delta$ : 27.0 (C-10), 26.5 (C-9), 30.6 (C-8), 35.9 (C-4), 45.6 (C-7), 47.3 (C-5), 66.8 (C-6), 86.7 (C-7a), 112.9 (C3), $171.9(\mathrm{C}-2), 182.4$ (C-3a). These data were compared with the data reported by Park et al. (2004), and the compound was recognized as (-)-loliolide (Fig. 4).

Compound $2\left(1.5 \mathrm{mg}\right.$ ) had a molecular formula of $\mathrm{C}_{13} \mathrm{H}_{20} \mathrm{O}_{3}$ (LR-ESI-MS m/z, 225 $[\mathrm{M}+\mathrm{H}]^{+}$and $\left.247[\mathrm{M}+\mathrm{Na}]^{+}\right)$and a specific rotation of $[\alpha]_{\mathrm{D}}{ }^{25}-10.6\left(c 0.01, \mathrm{CHCl}_{3}\right)$. The following were obtained for NMR spectra: ${ }^{1} \mathrm{H}-\mathrm{NMR}\left(400 \mathrm{MHz}, \mathrm{CDCl}_{3}\right) \delta: 0.98(\mathrm{~s}$, H-11), 1.19 (s, H-12 and 13), 1.26 (m, H-2 $\beta$ ), 1.64 (dd, $J=14.7$ and $1.7 \mathrm{~Hz}, \mathrm{H}-4 \alpha$ ), $1.65(\mathrm{dd}, J=14.4$ and $8.6 \mathrm{~Hz}, \mathrm{H}-2 \alpha), 2.28(\mathrm{~s}, \mathrm{H}-10), 2.39$ (ddd, $J=14.4,5.0$ and $1.6 \mathrm{~Hz}, \mathrm{H}-4 \beta$ ), 3.90 (m, H-3), 6.29 (d, $J=15.6 \mathrm{~Hz}, \mathrm{H}-8$ ), 7.03 (d, $J=15.6 \mathrm{~Hz}, \mathrm{H}-7$ ); and ${ }^{13} \mathrm{C}-\mathrm{NMR}\left(100 \mathrm{MHz}, \mathrm{CDCl}_{3}\right) \delta$ : 19.9 (C-13), 25.0 (C-11), 28.3 (C-10), 29.3 (C-12), 35.1 (C-1), 40.6 (C-4), 46.7 (C-2), 64.0 (C-3), 67.2 (C-5), 69.5 (C-6), 132.6 (C-8), 142.3 (C-7), 197.4 (C-9). Therefore, the structure was $3 \beta$-hydroxy-5 $\alpha, 6 \alpha$-epoxy-7megastigmen-9-one (Fig. 4), which corresponds with the data reported by Duan et al. (2002).

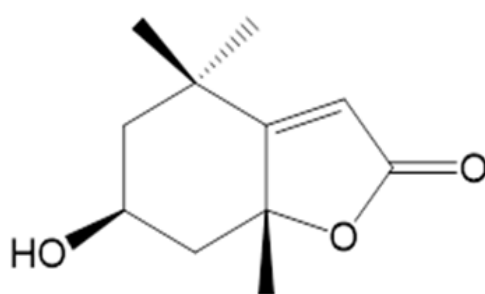

Compound 1

(-)-Loliolide

Chemical Formula: $\mathrm{C}_{11} \mathrm{H}_{16} \mathrm{O}_{3}$

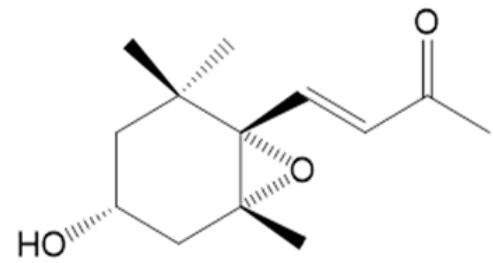

Compound 2

$3 \beta$-hydroxy-5 $\alpha, 6 \alpha$-epoxy-7-megastigmen-9-one Chemical Formula: $\mathrm{C}_{13} \mathrm{H}_{20} \mathrm{O}_{3}$

Figure 4. Structures of isolated allelochemicals (-)-loliolide (Compound 1) and 3 $\beta$-hydroxy$5 \alpha, 6 \alpha$-epoxy-7-megastigmen-9-one (Compound 2) from the Bangladeshi indigenous rice straw var. 'Goria'

The endogenous concentrations of (-)-loliolide and $3 \beta$-hydroxy-5 $\alpha, 6 \alpha$-epoxy-7megastigmen-9-one were at least 8 and $3 \mu \mathrm{mol} / \mathrm{kg}$, respectively, because 3.8 and $1.5 \mathrm{mg}$ of the respective substances (MW 196 and 224, respectively) were isolated from $2.4 \mathrm{~kg}$ DW of rice straw. With decomposition of $1 \mathrm{~kg}$ of rice straw in $1 \mathrm{~L}$ of soil water, the concentration of (-)-loliolide and $3 \beta$-hydroxy-5 $\alpha, 6 \alpha$-epoxy-7-megastigmen-9-one would be 8 and $3 \mu \mathrm{M}$, respectively.

\section{Biological activity of compounds}

Both identified compounds showed concentration and species-depended biological activities on seedling growth of test species (Figs. 5A, B and 6A, B). The results demonstrated that significant inhibitory effects of (-)-loliolide began at concentrations as low as $10 \mu \mathrm{M}$ on the root and shoot growth of L. sativum and at 10 and $30 \mu M$ on the root and shoot growth of E. oryzicola seedlings, respectively. However, significant inhibitory effects of $3 \beta$-hydroxy-5 $\alpha, 6 \alpha$-epoxy-7-megastigmen-9-one began at the 
concentrations $0.3 \mu \mathrm{M}$ on the root and shoot growth of L. sativum and 0.3 and $1 \mu \mathrm{M}$ on the root and shoot growth of E. oryzicola seedlings, respectively. The mixture effect of the two compounds at concentrations as low as 0.03 and 0.1 , and $1 \mu \mathrm{M}$ showed significant inhibition of the root and shoot growth of L. sativum and E. oryzicola seedlings (Figs. 7 and 8). Additionally, the inhibitory effects increased with increasing concentrations of the compounds. The concentrations causing approximately $50 \%$ growth inhibition in the assay (defined as $I_{50}$ ) for $L$. sativum roots and shoots were 28.23 and $53.4,1.26$ and 2.14 , and 0.26 and $0.33 \mu \mathrm{M}$ for (-)-loliolide, $3 \beta$-hydroxy-5 $\alpha, 6 \alpha$ epoxy-7-megastigmen-9-one and their mixture, respectively. For E. oryzicola roots and shoots, the $I_{50}$ values were 64.62 and 162.92 , 43.28 and 137.64 , and 2.31 and $17.86 \mu \mathrm{M}$ for (-)-loliolide, $3 \beta$-hydroxy-5 $\alpha, 6 \alpha$-epoxy-7-megastigmen-9-one and their mixture, respectively (Table 3$)$.
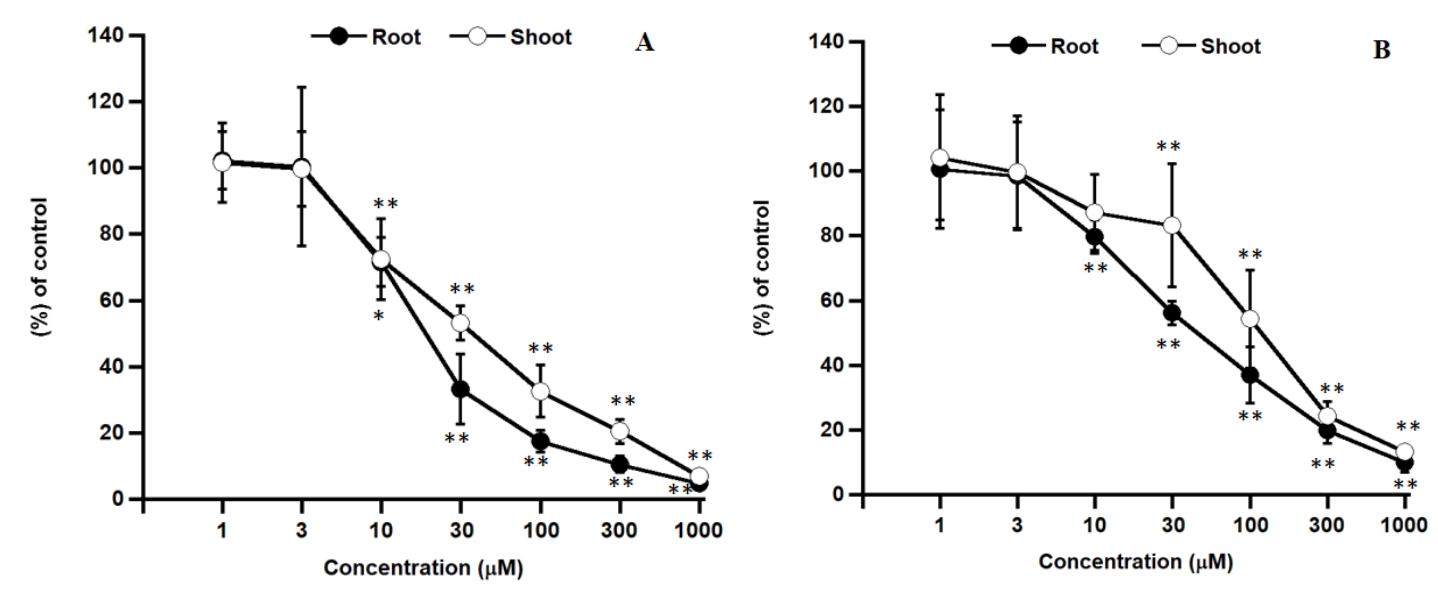

Figure 5. Inhibition of root and shoot growth of L. sativum (A) and E. oryzicola (B) at different concentrations of (-)-loliolide. Bars represent $\pm S D$ of values obtained from three biological replicates. Asterisks indicate significant differences between the control and treatment:

$$
* P<0.05 ; * * P<0.01
$$
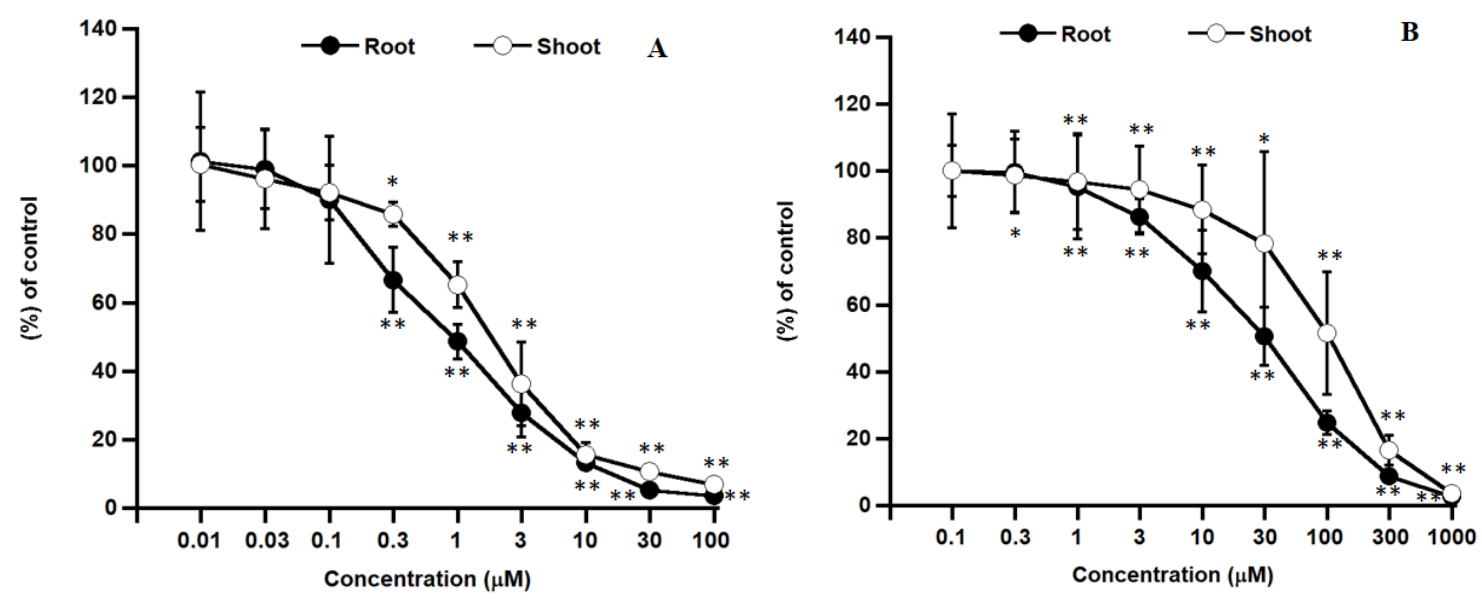

Figure 6. Inhibition of root and shoot growth of L. sativum (A) and E. oryzicola $(B)$ at different

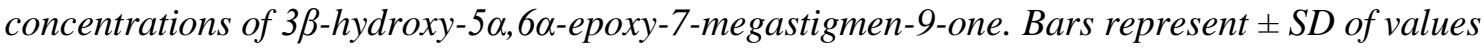
obtained from three biological replicates. Asterisks indicate significant differences between the control and treatment: $* P<0.05 ; * * P<0.01$ 

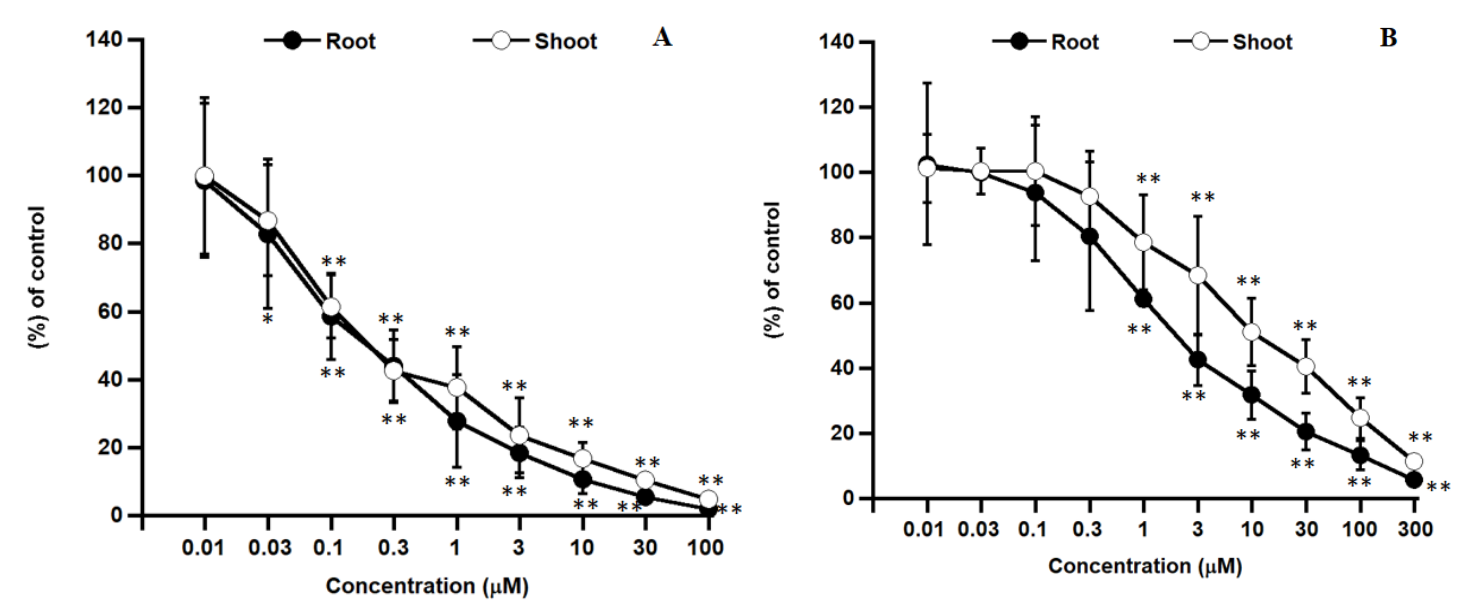

Figure 7. Inhibition of root and shoot growth of L. sativum (A) and E. oryzicola (B) at different

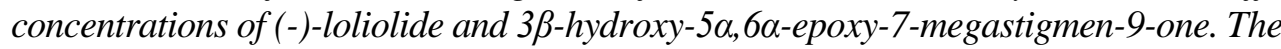

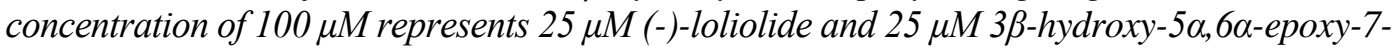
megastigmen-9-one. Bars represent $\pm S D$ of values obtained from three biological replicates. Asterisks indicate significant differences between the control and treatment: $* P<0.05 ; * * P<0.01$

Table 3. Regression analyses of dose response curves for effects on L. sativum and E. oryzicola growth at different concentrations of the isolated compounds and their mixture

\begin{tabular}{|c|c|c|c|c|c|c|c|}
\hline \multirow{2}{*}{ Test species } & \multirow{2}{*}{ Compound } & \multicolumn{3}{|c|}{ On root } & \multicolumn{3}{|c|}{ On shoot } \\
\hline & & Regression equation & $r^{2}$ & $I_{50}(\mu \mathrm{M})$ & Regression equation & $r^{2}$ & $I_{50}(\mu \mathrm{M})$ \\
\hline \multirow{3}{*}{ L. sativum } & 1 & $y=-0.502 x+64.17$ & 0.729 & 28.23 & $y=-0.403 x+71.50$ & 0.916 & 53.40 \\
\hline & 2 & $y=-13.54 x+67.03$ & 0.949 & 1.26 & $y=-17.49 x+87.46$ & 0.970 & 2.14 \\
\hline & Mixture & $y=-31.31 x+58.03$ & 0.924 & 0.26 & $y=-21.41 x+57.14$ & 0.644 & 0.33 \\
\hline \multirow{3}{*}{ E. oryzicola } & 1 & $y=-0.422 x+77.27$ & 0.870 & 64.62 & $y=-0.202 x+82.91$ & 0.932 & 162.92 \\
\hline & 2 & $y=-0.467 x+70.21$ & 0.946 & 43.28 & $y=-0.216 x+79.73$ & 0.962 & 137.64 \\
\hline & Mixture & $y=-12.96 x+79.89$ & 0.922 & 2.31 & $y=-0.919 x+66.41$ & 0.840 & 17.86 \\
\hline
\end{tabular}

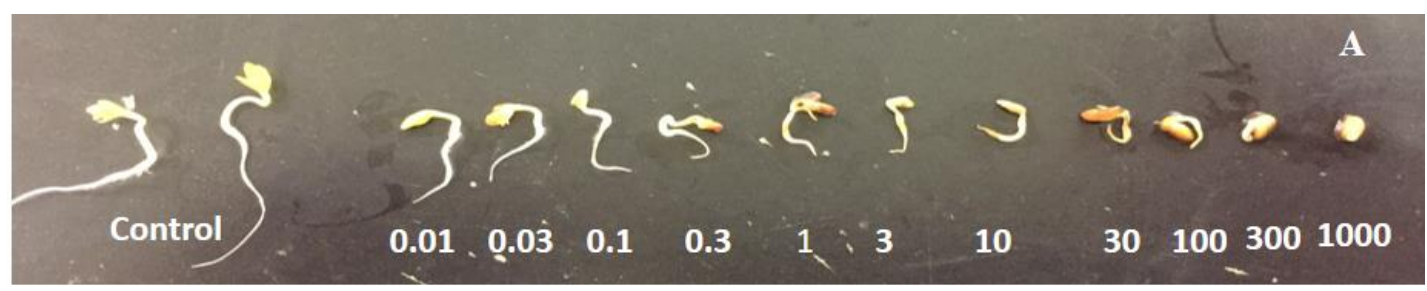

Concentration $(\mu \mathrm{M})$

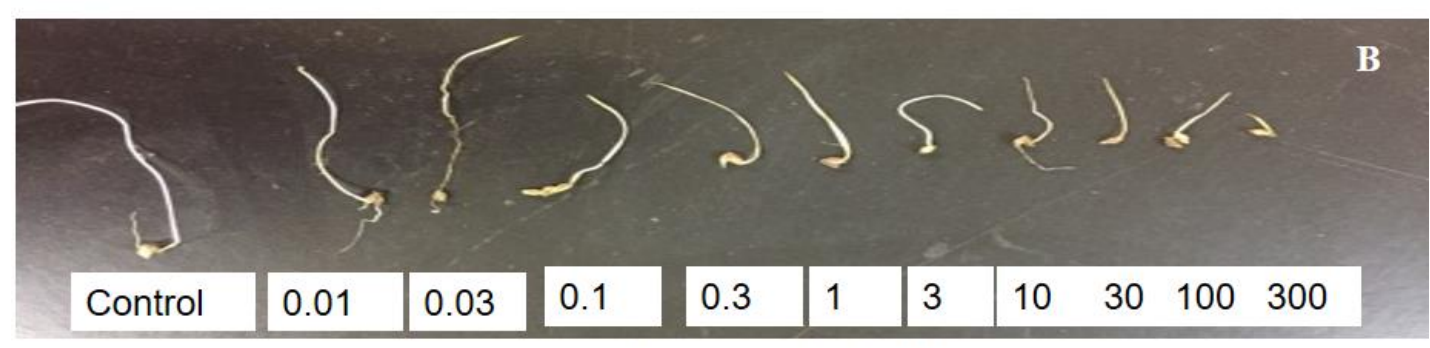

Concentration $(\mu \mathrm{M})$

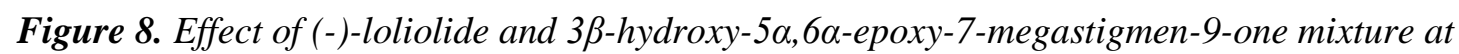
different concentrations on $(A) L$. sativum and $(B)$ E. oryzicola seedlings 


\section{Discussion}

The results described here clearly shown that 'Goria' rice straw was very toxic to $E$. oryzicola with significant reductions in seedling growth and dry weight. These results indicate that decomposing rice straw contained inhibitory substances that can reduce the growth of weeds. Kong et al. (2006) found that the weed growth reduction in rice straw incorporated soils through release of allelochemicals. A sharp increase of rice growth and yield parameters was observed in the rice culture in pot studies. Therefore, no autotoxicity effect on the growth and yield parameters of rice was found due to the incorporation of rice residues. The rice plant may develop adaptive mechanisms to avoid a severe autotoxic effect due to the surplus impact of disintegrating rice residues (Chou, 1980). Xuan et al. (2005) reported that incorporation of allelopathic rice straw at 1-2 t ha ${ }^{-1}$ decreased weed dry matter by about $70 \%$ and boosted rice yield by almost $20 \%$ compared with the respective controls. According to Dobermann and Fairhurst (2002), incorporation of rice straw by shallow tillage at the $5-10 \mathrm{~cm}$ depth has beneficial effects on soil fertility in intensive rice-rice systems, which include increased soil aeration during fallow periods, more complete carbon (C) turnover (approximately 50\% of the $\mathrm{C}$ with 30-40 days), minimized negative effects (e.g., phytotoxicity) of the products of anaerobic decomposition on early rice growth, amplified $\mathrm{N}$ mineralization and soil $\mathrm{P}$ release to the next crop, and lessened weed growth. Moreover, results of rice straw incorporation are very encouraging since it helps in buildup of organic carbon (Nagargade et al., 2018). The aqueous methanol extract of Bangladeshi indigenous rice 'Goria' straw reduced the root and shoot growth of the test plant species, and with increases in the concentration of the extract, the inhibition increased. Xiao et al. (2020) demonstrated that allelopathic rice straw extract exerted inhibition effects on lettuce (Lactuca sativa Linn.) seed germination. Kawther et al. (2006) reported that rice straw extract potentially controlled E. crus-galli and E. colona. Anuar et al. (2015) also found that the radicle length of E. crus-galli was significantly reduced in the increased extract concentration of rice straw. In our studies, both stimulatory and inhibitory effects were found. Duke (2015) reported that allelopathic activity could have stimulatory results at a low concentration and an inhibitory effect at a high concentration depending on the allelopathic compounds. Inderjit and Duke (2003) also found different allelopathic responses for asymmetrical test plants due to the different selectivity of allelopathic substances. Grabarczyk et al. (2015) noted that (-)-loliolide inhibited the development of certain plants, and Islam et al. (2017) also found that loliolide reduced the seedling growth of E. crus-galli. Duan et al. (2002) isolated $3 \beta$-hydroxy-5 $\alpha, 6 \alpha$-epoxy-7megastigmen-9-one from Saussurea medusa as an immunosuppressive constituent. Masum et al. (2018) found that $3 \beta$-hydroxy-5 $\alpha, 6 \alpha$-epoxy-7-megastigmen-9-one inhibited the radicle growth of E. crus-galli. Lu et al. (2011) isolated (-)-loliolide and $3 \beta$-hydroxy-5 $\alpha, 6 \alpha$-epoxy-7-megastigmen-9-one from Gracilaria lemaneiformis and described their allelopathic potential on the alga Skeletonema costatum. Growth inhibition of test species increased significantly with the mixture of the two compounds compared with the inhibition of the individual compounds. Chotsaeng et al. (2017) reported that allelopathic effects depend on the concentrations, the combination of phytotoxins and sensitivity of flora and suggested that allelopathic compound mixtures could collectively reach sufficiently high concentrations to be bioactive on weeds. Hence, verified allelochemicals could be leads for new herbicide innovation efforts (Kong et al., 2019). 


\section{Conclusion}

Bangladesh indigenous allelopathic rice 'Goria' straw incorporation into the soil gave inhibitory effects on the growth and dry weight of E. oryzicola but had no autotoxicity on the growth of rice variety. Isolated two biologically active compounds from straw extracts, (-)-loliolide and 3 $\beta$-hydroxy-5 $\alpha, 6 \alpha$-epoxy-7-megastigmen-9-one had a strong synergistic inhibitory effect on the growth of tested weed. Thus, our current work suggests that Bangladesh indigenous rice straw variety 'Goria' could be useful in multidisciplinary approaches for suppressing weeds and/or decreasing the synthetical quantities and for soil nutrient improvement. Overall, based on such studies, the use of rice residues for overcoming weeds problem in crop production might be considered as a noteworthy accomplishment for the retrieving of straw in rice growing countries such as Bangladesh, which will be displayed in reductions of the effects of environmental pollution. These results also provide fundamental information for developing natural herbicides.

Acknowledgements. The authors acknowledge the Ministry of Education, Culture, Sports, Science and Technology (MEXT), Japan for providing scholarship to the first author.

Conflict of interests. The authors declare no conflict of interests.

\section{REFERENCES}

[1] Amb, M. K., Ahluwalia, A. S. (2016): Allelopathy: potential role to achieve new milestones in rice cultivation. - Rice Science 23: 165-183.

[2] Anuar, F. D. K., Ismail, B. S., Ahmad, W. J. W. (2015): Allelopathy effect of rice straw on the germination and growth of Echinochloa crus-galli (L.) P. Beauv. - AIP Conference Proceedings 1678: 020014.

[3] Anwar, T., Ilyas, N., Qureshi, R., Qureshi, H., Gilani, N., Khan, S., Khan, S. A., Fatimah, H., Waseem, M., Maqsood, M. (2019): Evaluation of phytotoxic potential of selected plants against weeds. - Applied Ecology and Environmental Research 17: 12683-12696.

[4] BBS (Bangladesh Bureau of Statistics) (2017): Year book of agricultural statistics-2016. http://bbs.portal.gov.bd/sites/default/files/files/bbs.portal.gov.bd/page/1b1eb817_9325_435 4_a756_3d18412203e2/Yearbook-2016-Final-19-06-2017.pdf. Accessed 6 July 2017.

[5] Cao, N. Y., Wang, P., Kong, C. H. (2008): Effects of lignin from allelopathic and nonallelopathic rice straws on Echinocholoa crus-galli and soil microorganisms. Allelopathy Journal 22: 397-402.

[6] Cheema, Z. A., Khaliq, A., Saeed, S. (2004): Weed control in maize (Zea mays L.) through sorghum allelopathy. - Journal of Sustainable Agriculture 23: 73-86.

[7] Chotsaeng, N., Laosinwattana, C., Charoenying, P. (2017): Herbicidal activities of some allelochemicals and their synergistic behaviors toward Amaranthus tricolor L. Molecules 22: 1841.

[8] Chou, C. H. (1980): Allelopathic researches in subtropical vegetation in Taiwan. Comparative Physiology and Ecology 5: 222-234.

[9] Chung, I. M., Ahn, J. K., Yun, S. J. (2001): Identification of allelopathic compounds from rice (Oryza sativa L.) straw and their biological activity. - Canadian Journal of Plant Science 81: 815-819.

[10] Chung, I. M., Kim, S. H., Oh, Y. T., Ali, M., Ahmed, A. (2017): New constituents from Oryza sativa L. straw and their algicidal activities against blue-green algae. - Allelopathy Journal 40: 47-62. 
[11] Dayan, F. E., Cantrell, C. L., Duke, S. O. (2009): Natural products in crop protection. Bioorganic \& Medicinal Chemistry 17: 4022-4034.

[12] Dobermann, A., Fairhurst, T. H. (2002): Rice Straw Management. - In: Armstrong, D. L., Griffin, K. P (eds.) Better Crops International. Vol 16. International Plant Nutrition Institute, Saskatchewan, pp. 7-11.

[13] Duan, H., Takaishi, Y., Momota, H., Ohmoto, Y., Taki, T. (2002): Immunosuppressive constituents from Saussurea medusa. - Phytochemistry 59: 85-90.

[14] Duke, S. O. (2015): Proving allelopathy in crop-weed interactions. - Weed Science 63: 121-132.

[15] Erisman, J. W., Sutton, M. A., Galloway, J., Klimont, Z., Winiwarter, W. (2008): How a century of ammonia synthesis changed the world. - Nature Geoscience 1: 636-639.

[16] Grabarczyk, M., Winska, K., Mączka, W., Potaniec, B., Aniol, M. (2015): Loliolide - the most ubiquitous lactone. - Folia Biologica et Oecologica 11: 1-8.

[17] Han, X., Cheng, Z. H., Meng, H. W., Yang, X. L., Ahmad, I. (2013): Allelopathic effect of decomposed garlic (Allium sativum L.) stalk on lettuce (L. sativa var. crispa L.). Pakistan Journal of Botany 45: 225-233.

[18] Inderjit, Duke, S. O. (2003): Ecophysiological aspects of allelopathy. - Planta 217: 529539.

[19] Inderjit, Rawat, D. S., Foy, C. L. (2004): Multifaceted approach to determine rice straw phytotoxicity. - Canadian Journal of Botany 82: 168-176.

[20] Islam, M. S., Iwasaki, A., Suenaga, K., Kato-Noguchi, H. (2017): Isolation and identification of two potential phytotoxic substances from the aquatic fern Marsilea crenata. - Journal of Plant Biology 60: 75-81.

[21] Jabran, K., Mahajan, G., Sardana, V., Chauhan, B. S. (2015): Allelopathy for weed control in agricultural systems. - Crop Protection 72: 57-65.

[22] Kato-Noguchi, H., Salam, M. A., Suenaga, K. (2011): Isolation and identification of potent allelopathic substances in a traditional Bangladeshi rice cultivar Kartikshail. Plant Production Science 14: 128-134.

[23] Kato-Noguchi, H., Tamura, K., Sasaki, H., Suenaga, K. (2012): Identification of two phytotoxins, blumenol A and grasshopper ketone, in the allelopathic Japanese rice variety Awaakamai. - Journal of Plant Physiology 169: 682-685.

[24] Kawther, G. E. R., El-Shahawy, T. A., Sharara, F. A. (2006): New approach to use rice straw waste for weed control. II. The effect of rice straw extract and Fusilade (herbicide) on some weeds infesting soybean (Glycin $\max$ L.). - International Journal of Agriculture \& Biology 8: 269-275.

[25] Khanh, T. D., Cong, L. C., Xuan, Y., Uezato, Y., Deba, F., Toyama, T., Tawata, S. (2009): Allelopathic plants: 20 hairy beggarticks (Bidens pilosa L.). - Allelopathy Journal. 24: 243-254.

[26] Kong, C. H., Li, H. B., Hu, F., Xu, X. H., Wang, P. (2006): Allelochemicals released by rice roots and residues in soil. - Plant and Soil. 288: 47-56.

[27] Kong, C. H., Xuan, T. D., Khanh, T. D., Tran, H. D., Trung, N. T. (2019): Allelochemicals and signaling chemicals in plants. - Molecules 24: 2737.

[28] Kraehmer, H., Jabran, K., Mennan, H., Chauhan, B. S. (2016): Global distribution of rice weeds - a review. - Crop Protection 80: 73-86.

[29] Lu, H., Xie, H., Gong, Y., Wang, Q., Yang, Y. (2011): Secondary metabolites from the seaweed Gracilaria lemaneiformis and their allelopathic effects on Skeletonema costatum. - Biochemical Systematics and Ecology 39: 397-400.

[30] Lund, M. C., Carter, P. R., Oplinger, E. S. (1993): Tillage and crop rotation affect corn, soybean and winter wheat yields. - Journal of Production Agriculture 6: 425-431.

[31] Masum, S. M., Hossain, M. A., Akamine, H., Sakagami, J. I., Bhowmik, P. C. (2016): Allelopathic potential of indigenous Bangladeshi rice varieties. - Weed Biology and Management 16: 119-131. 
[32] Masum, S. M., Hossain, M. A., Akamine, H., Sakagami, J. I., Ishii, T., Gima, S., Kensaku, T., Bowmik, P. C. (2018): Isolation and characterization of allelopathic compounds from the indigenous rice variety 'Boterswar' and their biological activity against Echinochloa crus-galli L. - Allelopathy Journal 43: 31-42.

[33] Nagargade, M., Singh, M. K., Tyagi, V. (2018): Ecologically sustainable integrated weed management in dry and irrigated direct-seeded rice. - Advances in Plants \& Agriculture Research 8: 319-331.

[34] Park, K. E., Kim, Y. A., Jung, H. A., Lee, H. J., Ahn, J. W., Lee, B. J., Seo, Y. (2004): Three norisoprenoids from the brown alga Sargassum thunbergii. - Journal of the Korean Chemical Society 48: 394-398.

[35] Rahman, M. A., Chikushi, J., Safizzaman, M., Lauren, J. G. (2005): Rice straw mulching and nitrogen response of no-till wheat following rice in Bangladesh. - Field Crops Research 91: 71-81.

[36] Ramakrishna, A., Hoang, M. T., Wani, S. P., Tranh, D. L. (2006): Effect of mulch on soil temperature, moisture, weed infestation and yield of groundnut in northern Vietnam. Field Crops Research 95: 115-125.

[37] Schreiber, M. M. (1992): Influence of tillage, crop rotation, and weed management on giant foxtail population dynamics and corn yield. - Weed Science 40: 645-653.

[38] Weidenhamer, J. D., Callaway, R. M. (2010): Direct and indirect effects of invasive plants on soil chemistry and ecosystem function. - Journal of Chemical Ecology 36: 5969.

[39] Weir, T. L., Park, S. W., Vivanco, J. M. (2004): Biochemical and physiological mechanisms mediated by allelochemicals. - Current Opinion in Plant Biology 7: 472479.

[40] Weston, L. A., Duke, S. O. (2003): Weed and crop allelopathy. - Critical Reviews in Plant Sciences 22: 367-389.

[41] Xiao, Z., Zou, T., Lu, S., Xu, Z. (2020): Soil microorganisms interacting with residuederived allelochemicals effects on seed germination. - Saudi Journal of Biological Sciences 27: 1057-1065.

[42] Xuan, T. D., Shinkichi, T., Khanh, T. D., Min, C. I. (2005): Biological control of weeds and plant pathogens in paddy rice by exploiting plant allelopathy: an overview. - Crop Protection 24: 197-206.

[43] Yang, X. F., Kong, C. H. (2017): Interference of allelopathic rice with paddy weeds at the root level. - Plant Biology 19: 584-591. 